\title{
Current Status of Levodopa Therapy in Idiopathic Parkinson's Disease
}

\author{
S. Gauthier and L. Gauthier
}

\begin{abstract}
Levodopa is currently used at all stages of Parkinson's disease, particularly from Stage 3 onward. Most patients start levodopa within four years of the onset of disease, earlier in the akineto-rigid patients (average delay of 2.1 years) than in those where resting tremor predominates (average delay of 3.4 years). Advanced age ( $>80)$ is no deterrent to the use of levodopa if required. Wearing off is most noticeable in Stage 3 or after 10 years of therapy with levodopa. An inverse correlation was found between age and wearing off, suggesting a marked sensitivity of younger patients to levodopa. Future studies on the use of dopamine agonists should thus be stratified according to age.
\end{abstract}

RÉSUMÉ: Le statut courant de la thérapie à levodopa dans la maladie de Parkinson La levodopa est actuellement utilisée à tous les stades de la Maladie de Parkinson, surtout à partir du Stade 3. La plupart des patients débutent la levodopa avant la quatrième année de leur maladie, plus tôt chez ceux qui ont la forme akinéto-rigide (délai moyen de 2.1 années) que chez ceux où le tremblement prédomine (délai moyen de 3.4 années). Un âge avancé $(>80)$ n'empêche pas l'utilisation de la levodopa si nécessaire. La perte d'efficacité est plus détectable au Stade 3 ou après 10 années de traitement avec la levodopa. Une corrélation inverse a été trouvée entre l'âge et la perte d'efficacité, suggérant une sensibilité particulière des jeunes Parkinsoniens à la levodopa. Les études futures sur l'utilisation des agonistes dopaminergiques devraient donc être stratifiées selon l'âge.

Can. J. Neurol. Sci. 1987; $14: 452-454$

The controversies surrounding the use of levodopa for Idiopathic Parkinson's disease (IPD) discussed at the Symposium held in Montebello, Quebec, October 1983, and published in this Journal in February 1984 centered on the early versus late use of this medication ${ }^{1,2}$ and on the therapeutic value of levodopa drug holidays. ${ }^{3}$ Since then, there has been a general consensus that levodopa should be started when the functional needs of the individual patient warrant it, using amounts as low as possible. ${ }^{4}$ Bromocriptine is added in progressive doses when a 4 times a day schedule of levodopa does not give adequate clinical benefit. ${ }^{4}$ Levodopa drug holidays have lost their rationale since the report that D2 dopamine receptors density is not reduced by chronic levodopa therapy. ${ }^{5}$ Furthermore these drug holidays proved to have a low benefit/risk ratio. ${ }^{6}$

To illustrate the current status of levodopa therapy, a descriptive retrospective study was conducted on the charts of 270 patients with IPD followed at the McGill Movement Disorder Clinic. The specific questions asked were: which patients are taking levodopa and when was this therapy started in the course of the illness? How often is wearing off experienced in regard to the type of symptoms, the stage of disease, duration of disease and of treatment, and finally the age of the patients?

\section{METHODS}

The medical records of 270 patients suffering from IPD and under active treatment (seen within the last six months of 1986) were studied for the following parameters: year of birth, current stage of disease, ${ }^{7}$ predominant symptom (akineto-rigid, resting tremor or mixed symptoms), ${ }^{8}$ year of onset of predominant symptom, on-going treatment with levodopa. Furthermore the year of onset of levodopa therapy, the detectability of a latency of action and the detectability of wearing off were examined. Latency of action was defined as the time elapsed before the earliest detectable motor response (usually asymmetric dyskinesias) to individual doses of levodopa. Wearing off was defined as the time interval between the onset of action of individual doses of levodopa and the loss of motor response (usually akinesia or tremor with asymmetric dystonia). Detectable was defined as present on at least 3 follow-up visits. Latency of action ranged from 10 to 60 minutes whereas duration of action ranged from 1 to 4 hours.

All patients were actively followed by the same neurologist (S.G.) but many had their levodopa therapy initiated by other neurologists. These observations on the use of levodopa can thus be considered as representative of the pattern of practice

From the McGill Centre for Studies in Age and Aging and the School of Physical and Occupational Therapy, McGill University

Reprint requests to: Dr. S. Gauthier, Director, McGill Centre for Studies in Age and Aging, 1650 Cedar Ave., Montréal, Québec, Canada H3G 1A4 
by neurologists in the Greater Montreal area. Sinemet 100/25 and Prolopa 100/25 constitute the standard levodopa preparations used, from tid to qid, q 3 hours, then q 2 hours when awake. Levodopa has been tried in most patients but continued only if found to be of clinical benefit. Only a small proportion of patients currently take bromocriptine (less than $5 \%$ ).

\section{RESULTS}

\section{General features of the IPD population studied}

The mean age of onset among the 270 patients was 58.3 years, their current mean age 65.9 and their average stage of disease 2.97 (Hoehn and Yahr scale of 1 to 5; reference 7). Subdivision according to the predominant symptom(s) showed $18 \%$ to akinetic, $16 \%$ to have tremor at rest as the sole or predominant symptom and $66 \%$ to have mixed symptoms (Table 1). There was no difference in age of onset, duration or stage of disease between these sub-groups.

\section{Use of levodopa}

The use of levodopa was less in the group of patients with tremor at rest. Only $59 \%$ of these patients found levodopa to be effective and were still taking it, in contrast to $94 \%$ of the akinetic patients and $91 \%$ of those with mixed symptoms (Table 1).

A difference in the timing of initiation of levodopa therapy was also documented between akinetic patients ( 2.1 years) and those with tremor ( 3.4 years).

Levodopa was used at all stages of IPD and in nearly all patients from stage 3 onward (Table 2). Most patients were on levodopa after the 4 th year of IPD. Conversely, $30 \%$ of patients did not use it before the 5 th year (Table 3 ). Levodopa was used at all ages (Table 4).

\section{Wearing off}

In this study, the presence of a detectable latency of action and wearing off was considered as an index of excessive reactivity to levodopa. As can be seen in all tables ( 1 to 5 ), wearing off was detectable by fewer patients than a latency to onset of action. Only $26 \%$ of patients with tremor at rest as the sole or predominant symptom of IPD experienced wearing off as compared to $49 \%$ of the akinetic patients (Table 1).

Wearing off was most apparent in patients with stage 3 disease (Table 2), after the 9th year of disease (Table 3), after the 9th year of treatment with levodopa (Table 5), and in the younger patients (Table 4).
Table 1: Temporal characteristics of the disease and use of levodopa in relation to predominant symptom

\begin{tabular}{|c|c|c|c|}
\hline & \multicolumn{3}{|c|}{ Disease type } \\
\hline & $\begin{array}{c}\text { Akineto } \\
\text { rigid }\end{array}$ & Tremor & $\begin{array}{c}\text { Mixed } \\
\text { symptoms } \\
\end{array}$ \\
\hline Number of subjects & $49(18 \%)$ & $44(16 \%)$ & $177(66 \%)$ \\
\hline Age at onset* & $55.8 \pm 11.3$ & $60.8 \pm 10.1$ & $58.4 \pm 10.6$ \\
\hline Duration of disease* & $6.8 \pm 5.6$ & $7.0 \pm 5.8$ & $8.3 \pm 6.0$ \\
\hline Current disease stage ${ }^{* *}$ & $3.0 \pm 1.0$ & $2.6 \pm 1.0$ & $3.1 \pm 1.1$ \\
\hline \% on levodopa & $94 \%$ & $59 \%$ & $91 \%$ \\
\hline $\begin{array}{l}\text { Interval between onset of } \\
\text { disease and initiation of } \\
\text { levodopa therapy* }\end{array}$ & $2.1 \pm 3.2$ & $3.4 \pm 2.9$ & $2.7 \pm 3.6$ \\
\hline $\begin{array}{l}\text { Duration of levodopa } \\
\text { therapy* }\end{array}$ & $5.3 \pm 3.9$ & $5.0 \pm 5.4$ & $6.2 \pm 4.6$ \\
\hline $\begin{array}{l}\text { \% with detectable latency } \\
\text { of action }\end{array}$ & $49 \%$ & $37 \%$ & $45 \%$ \\
\hline$\%$ with detectable wearing off & $49 \%$ & $26 \%$ & $41 \%$ \\
\hline
\end{tabular}

* years; mean $\pm \mathrm{SD}$

** Hoehn and Yahr, reference 7

\begin{tabular}{|c|c|c|c|c|}
\hline Stage $(*)$ & $\mathbf{N}$ & $\begin{array}{c}\% \text { on } \\
\text { DOPA }\end{array}$ & $\begin{array}{c}\text { \% with } \\
\text { latency of } \\
\text { action }\end{array}$ & $\begin{array}{c}\% \text { with } \\
\text { wearing off }\end{array}$ \\
\hline 1 & 26 & 54 & 44 & 20 \\
\hline 2 & 58 & 74 & 44 & 42 \\
\hline 3 & 95 & 91 & 49 & 48 \\
\hline . 4 & 75 & 95 & 48 & 42 \\
\hline 5 & 16 & 100 & 25 & 25 \\
\hline
\end{tabular}

* Hoehn and Yahr, reference 7

Table 3: Duration of disease and use of levodopa

\begin{tabular}{ccccc}
$\begin{array}{c}\text { Duration of } \\
\text { disease (yrs) }\end{array}$ & N & $\begin{array}{c}\text { \% on } \\
\text { DOPA }\end{array}$ & $\begin{array}{c}\text { \% with } \\
\text { latency of } \\
\text { action }\end{array}$ & $\begin{array}{c}\text { \% with } \\
\text { wearing off }\end{array}$ \\
\hline $1-2$ & 28 & 67 & 27 & 25 \\
$3-4$ & 58 & 71 & 27 & 24 \\
$5-9$ & 111 & 94 & 41 & 38 \\
$10-14$ & 43 & 95 & 71 & 66 \\
$>15$ & 30 & 93 & 57 & 54 \\
\hline
\end{tabular}

\begin{tabular}{|c|c|c|c|c|c|c|}
\hline $\begin{array}{c}\text { Current } \\
\text { age }\end{array}$ & $\mathbf{N}$ & $\begin{array}{c}\text { Duration } \\
\text { of disease* }\end{array}$ & $\begin{array}{c}\text { Stage of } \\
\text { disease** }\end{array}$ & $\begin{array}{c}\% \text { on } \\
\text { DOPA }\end{array}$ & $\begin{array}{c}\% \text { with } \\
\text { latency of } \\
\text { action }\end{array}$ & $\begin{array}{c}\% \text { with } \\
\text { wearing } \\
\text { off }\end{array}$ \\
\hline $40-49$ & 10 & $6.2 \pm 4.0$ & $2.6 \pm 0.9$ & 90 & 78 & 78 \\
\hline $50-59$ & 56 & $6.0 \pm 3.7$ & $2.2 \pm 1.0$ & 90 & 54 & 52 \\
\hline$>80$ & 21 & $9.0 \pm 8.5$ & $3.7 \pm 0.8$ & 86 & 22 & 22 \\
\hline
\end{tabular}

* years; mean $\pm \mathrm{SD}$

** Hoehn and Yahr, reference 7 


\begin{tabular}{cccc}
\hline \begin{tabular}{c} 
Table 5: Duration of levodopa therapy and reactivity \\
\hline \hline \\
Dureatment (yrs)
\end{tabular} & $\mathbf{N}$ & $\begin{array}{c}\text { \% with } \\
\text { latency of } \\
\text { action }\end{array}$ & $\begin{array}{c}\text { \% with } \\
\text { wearing off }\end{array}$ \\
\hline $1-2$ & 70 & 19 & 16 \\
$3-4$ & 42 & 55 & 43 \\
$5-6$ & 74 & 55 & 51 \\
$10-14$ & 30 & 80 & 73 \\
$>15$ & 16 & 44 & 44 \\
\hline
\end{tabular}

\section{Discussion}

These data support what we suspect to be common clinical practice $-a$ tendency for physicians to individualize therapy for IPD according to the predominant symptom(s). Thus akinetorigid patients need and receive levodopa earlier in the course of the disease than those with tremor. Patients with predominantly resting tremor are given anticholinergic drugs, antihistaminics and amantadine prior to the use of levodopa, or find these medications more effective than levodopa.

Levodopa is clearly the drug of choice in IPD and eventually most (if not all) patients will receive it. Clinical benefit may not be obvious at the first trial and levodopa is often withdrawn, to be tried again later. Early gastro-intestinal side-effects are easily controlled with agents such as domperidone. ${ }^{9}$ The late motor fluctuations may be partly prevented by the early combination of direct dopamine agonists and levodopa. ${ }^{10}$

Our data show that wearing off, a manifestation of abnormal reactivity to and reduced efficacy of levodopa, is present maximally in stage 3 , after 10 to 14 years of disease or treatment, and in younger patients. To explain the loss of efficacy and fluctuations in the motor response to levodopa, the importance of changes in proportion of high-affinity and low-affinity states of striatal D2 dopamine receptors rather than drop-out of D2 receptors has been suggested by Guttman et al. ${ }^{5}$ These changes may clearly be present in individuals treated with levodopa for only a short period of time, such as children with parkinson syndromes, " young adults with MPTP-induced parkinsonism ${ }^{12}$ and the young adults with IPD in this study. The severity of disease in the nigro-striatal system would thus determine the initial clinical response and then the loss of reactivity to levodopa. Future drug studies with dopamine agonists should thus be stratified according to age groups, at least to differentiate the response of the early-onset IPD patients from the older ones.

Another possible mechanism for loss of efficacy is faulty absorption of levodopa from the gut. This is supported by observations that stabilization of clinical signs can be achieved by intravenous infusion of levodopa ${ }^{13}$ and by direct duodenal continuous infusion of levodopa. ${ }^{14}$ Nutritional studies in IPD would thus be of value in regard to the effects of chronic amino-acid intake and age on the intestinal absorption of levodopa.

Our data thus suggest that the age of the patient may be an important variable in determining the response to levodopa. Changes in D2 receptor affinity states may play a major role in the loss of efficacy to levodopa in younger patients because of the severity of pathology in the substantia nigra, whereas changes in intestinal absorption may be more important in elderly parkinsonians.

Future developments in the management of IPD may include prevention of further loss of substantia nigra neurons through anti-oxidant therapy, replacement of lost dopaminergic neurons by cell implants, and possibly environmental changes in subjects at risk. Non pharmacological interventions are also available such as physiotherapy for gait instability, group occupational therapy for ADL impairment and speech therapy for dysarthria, in order to stabilize patients at acceptable functional levels.

\section{REFERENCES}

1. Muenter MD. Should levodopa therapy be started early or late? Can J Neurol Sci 1984; 11: 195-199.

2. Fahn S, Bressman SB. Should levodopa therapy for parkinsonism be started early or late? Evidence against early treatment. Can J Neurol Sci 1984; 11: 200-206.

3. Kofman OS. Are levodopa "drug holidays" justified? Can J Neurol Sci 1984; 11: 206-209.

4. Calne DB, Rinne UK. Controversies in the management of Parkinson's disease. Mov Dis 1986; 1: 159-162.

5. Guttman M, Seeman P, Reynolds GP, et al. Dopamine D2 receptor density remains constant in treated Parkinson's disease. Ann Neurol 1986; 19: 487-492.

6. Mayeux R, Stern Y, Mulvey K, Cote L. Reappraisal of temporary levodopa withdrawal ("drug holiday") in Parkinson's disease. N Engl J. Med 1985; 313: 724-728.

7. Hoehn MM, Yahr MD. Parkinsonism: onset, progression and mortality. Neurology 1967; 17: 427-442.

8. Barbeau A, Roy M. Familial subsets in idiopathic Parkinson's disease. Can J Neurol Sci 1984; 11: 144-150.

9. Parkes JD. Domperidone and Parkinson's disease. Clin Neuropharmacol 1986; 9: 517-532.

10. Rinne UK. Combined bromocriptine-levodopa therapy early in Parkinson's disease. Neurology 1985; 35: 1196-1 198.

11. Lang AE, Meadows JC, Parkes JD, Marsden CD. Early onset of the "on-off" phenomenon in children with symptomatic parkinsonism. J Neurol Neurosurg Psychiatry 1982; 45: 823-825.

12. Langston JW, Ballard P. Parkinsonism induced by MPTP: implications for treatment and pathogenesis of Parkinson's disease. Can J Neurol Sci 1984; 11: 160-165.

13. Nutt JG, Woodward WR, Hammerstad JP, et al. The "on-off" phenomenon in Parkinson's disease. N Engl J Med 1984; 310 : 483-488.

14. Kurlan R, Rubin AJ, Miller C, et al. Duodenal delivery of levodopa for on-off fluctuations in parkinsonism: preliminary observations. Ann Neurol 1986; 20: 262-265. 